\title{
The Extended Person in Maya Ontology
}

\author{
Susan D. Gillespie
}

\begin{abstract}
:
For the Maya reality is a unified whole within which every entity shares in the same fundamental animating principle. This is a relational ontology whereby no phenomenon is self-contained but emerges from relations with others, including humans and non-humans, in various fields of action. This ontology correlates with a more encompassing "process metaphysic" in which reality is in constant flux, continually "becoming." The process metaphysic envisioned by philosopher Alfred North Whitehead provides a technical language for analyzing the composition and extension of Maya persons, using the model of personhood developed by anthropologist Marcel Mauss. In life individual Maya persons assembled divergent components endowed by their maternal and paternal ancestors, which were subsequently disassembled upon their deaths. They also assembled non-corporeal components-souls and names-that linked them to existences beyond the physical boundaries and timelines of their bodies. Aspects of personhood were also shared by objects worn or manipulated by humans. Persons were thus extended in space and in time, outliving individual human beings. Maya belief and practice reveals the fundamental process known as k'ex, "replacement" or "substitution," accounts for much of the flux and duration of the universe as a Maya-specific mode of "becoming."
\end{abstract}

Keywords: Maya, ontology, process metaphysic, personhood, Alfred North Whitehead

\section{Resumen:}

\section{LA NOCIÓN DE LA PERSONA EXTENDIDA EN LA ONTOLOGÍA MAYA}

Para los Mayas, el mundo real se concibe como un todo unificado en donde cada entidad comparte el mismo principio anímico. Se trata de una ontología relacional en la que ningún fenómeno es un ser contenido dentro de sí mismo, sino que surge de las relaciones con los demás, incluidos humanos y no humanos, en varios campos de acción. Esta ontología se correlaciona con una "metafísica del proceso" ("process metaphysic") según la cual la realidad se encuentra en flujo, en un continuo proceso de devenir ("becoming"). La metafísica del proceso prevista por el filósofo Alfred North Whitehead proporciona un lenguaje técnico para analizar la composición y extensión de la persona maya, utilizando el modelo de la personeidad ("personhood") elaborado por el antropólogo Marcel Mauss. Durante sus vidas las personas mayas individuales reunieron los componentes divergentes investidos por sus antepasados maternos y paternos, y que posteriormente, después de su muerte fueron desmontados. También reunieron los componentes no corporales - las almas y los nombres - que asociaron a sus presencias más allá de los

Susan D. Gillespie • Department of Anthropology, University of Florida, email: sgillesp@ufl.edu (D) https://orcid.org/0000-0002-6697-4268 
límites físico-temporales de los cuerpos mismos. Transfirieron ciertos aspectos de la personeidad a los objectos usados o manipulados por los humanos. De este modo ciertas personas se extienden en el espacio y en el tiempo, sobreviviendo a los seres humanos individuales. Las creencias y prácticas mayas se basan en el concepto fundamental de k'ex, ("reemplazo", "sustitución"), lo que explica en gran medida que un constante movimiento y la duración del universo constituyen un modo maya especifico de devenir.

Palabras claves: Maya, ontología, la metafísica del proceso, la persona, Alfred North Whitehead

\section{Introduction}

The twenty-first century is witnessing a growing interest by scholars in anthropology, archaeology, and related disciplines in "new" or alternative, nonWestern ontologies (e.g., Alberti and Bray 2009; Coole and Frost 2010; Alberti et al. 2011; Descola 2013; Watts 2013; Joyce 2015; Alberti 2016). Even philosophers are now exploring the different ontologies of indigenous America (e.g., Maffie 2014; McLeod 2018). This is part of a more general rejection in academia of the imposition of the modern Western world view on others. Especially targeted for criticism is the Western divide between humans and non-humans and the attribution of intention and agency only to humans. A near-universal animic ontology has been posited to characterize many non-Western perspectives, one in which animacy, agency, and personhood are not monopolized by humans but may be properties of non-human objects and intangible phenomena (e.g., Gell 1998; Latour 2005; Hendon 2012; Joyce 2015; Harrison-Buck and Hendon 2018; Watts 2013). Although its universality may be overstated, there is nevertheless greater acceptance in "counter-modern" thinking (Thomas 2004: 224) of the transcendence of Modernist oppositional categories, such as subject and object, culture and nature, divine and mortal, living and inert, and supernatural and natural, allowing for more complex polyagential realms of existence (e.g., Descola 2013; Kosiba et al. 2020; Zamora Corona 2020).

Overcoming our conventional human/non-human divide thus requires rethinking the status of "persons." Most notably, non-humans are being recognized within this category as sentient and agentive actors. Furthermore, the related modern Western concept of the "individual" must also be expanded beyond its narrow boundaries. Persons can be permeable, extendable, and plural, exceeding a single human body. They can also be durable, outliving that body. This paper reviews various aspects of Maya belief and practice regarding the relational and assembled person "in process," relying on the pioneering research of anthropologist Marcel Mauss and process philosophers such as Alfred North Whitehead.

In considering Maya personhood, I emphasize three major ontological propositions drawing from philosophy. The first is that personhood is a relational status (e.g., Fowler 2016). This is foundational to overcoming Modernist dualist ontologies (Watts 2013: 1). Entities assume their subjectivities-their characteristics 
and capacities-out of their relationships with others (Joyce 2015: 8). Persons are not isolable, reductive, or static. They are always parts of wholes that are more than the sums of their parts.

Relationism further involves the continual reconstitution of entities in alliance with other phenomena, forming various types of assemblages that are constituted, disassembled, and reconstituted over time (e.g., Latour 2005; DeLanda 2006; Harman 2008; Joyce 2012). Assemblages assume particular configurations based on the intrasubjectivities of their component parts within specific, but typically routine and generic, fields of action (Robb 2010).

These first two propositions are founded on an underlying process metaphysic whereby the universe is in flux, transformation is continuous, and entities are constantly emerging, constantly "becoming" (Rescher 1996, 2000; Halewood 2005). As difficult as it might be for Westerners to comprehend, what we call entities are better modeled as processes (Watts 2013: 1). A process metaphysic is becoming more common in anthropology, archaeology, and related disciplines (e.g., Gosden and Malafouris 2015).

I begin with a more detailed examination of this process metaphysic before discussing general notions of personhood. This theoretical review is followed by specific manifestations of the construction and durability of Maya persons from the prehispanic era to the present. Although conceptions of personhood among the Maya and within Mesoamerica more generally vary in specific ways, my focus here is on how different lines of data from the Maya region reveal evidence for a singular mechanism within a wider Mesoamerican process metaphysic, namely, the dynamic impulse of substitution or replacement encapsulated by the concept of k'ex.

\section{Mesoamerican Ontology: Monism and Teotlism}

Despite the diversity of cultures within Mesoamerica over the last 5000 years or so, anthropologists have identified a shared "monistic orientation" or "ontological monism" (e.g., Burkhart 1989: 36-37; Monaghan 2000: 26; Maffie 2014: 12, 22; McLeod 2018: 99). With ontological monism, reality is a unified whole in which every entity shares in the same fundamental animating principle. Not a tangible substance, it is usually understood as some kind of vital force, energy, or power. The Modern Western ontology, by contrast, is pluralistic, accepting the existence of divergent types of entities; for example, dividing humans from non-humans, or mortals from divine beings. A consequence of monism is a pantheistic conception of deity, in which all gods are different manifestations of this unitary vivifying force or power (Hunt 1977: 55-56). This monistic orientation has been called teotlism by some Mesoamerican scholars (following Klor de Alva 1979), from the Nahuatl word for this divine principle, teotl (see, e.g., Hvidtfeldt 1958), although others resist applying an Aztec concept to the rest of Mesoamerica (Monaghan 2000: 25). 
There are recognized shortcomings in our understandings of this nonplural ontology, some pointed out by John Monaghan (2000:29). For example, if there is an essential oneness of the universe, how can we explain its particular manifestationsthe different gods, humans, animals, and other beings? Moreover, the unity of this single force appears monolithic and "flat," seemingly incapable of accounting for change as something other than difference. It seems to invoke the ontological monovalence that is prevalent in Western science, according to philosopher Roy Bhaskar (Wallace 2011: 54). How can one explain the emergence of different superficial manifestations of an underlying divine principle? Does variation in time, space, or context play a role?

Fortunately, an influential recent book by philosopher James Maffie (2014), rethinking Aztec notions of teotl, provides some answers to these questions. Rather than power or force, Maffie (2014: 12) defines teotl as "process, movement, change, and transformation." Reality is a continual becoming or transition, not a state of being (2014: 12). More specifically, according to Maffie (2014: 137, emphasis in original), teotl as a process, a modus operandus of constant self-transformation, originates from "agonistic inamic unity, that is, the continual and continuous struggle (agon) of paired opposites, polarities, or dualities," such as life and death, male and female, day and night. The cosmos and everything within it is generated by this unending struggle of the dual facets of teotl. Balance is achieved over the long term in an "unchanging pattern of change according to which everything changes" (2014: 138-139; emphasis in original).

This ontology is holist and relationist. It accounts for the emergence of difference from the continuous interrelationships of assembling and disassembling entities as processes. Despite this clear explanation, however, the specific mechanisms of teotl need not apply to other monistic ontologies within Mesoamerica; this point remains to be investigated. Importantly, Maffie's ideas of teotl as process were shaped by the development of a "process metaphysic" in philosophy (Maffie 2014: 12). I turn now to this process metaphysic as a brief detour to help elucidate ontological monism among the Maya.

\section{Process Metaphysic}

What is called "process metaphysic" or "process philosophy" developed from the works of diverse philosophers from the eighteenth into the twentieth centuries, such as Gottfried Wilhelm Leibniz, Georg Wilhelm Friedrich Hegel, Charles Sanders Peirce, William James, Henri Bergson, and Alfred North Whitehead, although its basic premise-that in the universe "everything flows"goes back to Heraclitus in the sixth century BC (Browning 1965; Rescher 1996). Heraclitus's view was opposed by an alternative Greek "atomism" that viewed reality as composed of static substances or things (Rescher 1996: 9-11). Atomism was the 
basis for an Aristotelian metaphysic that dominated subsequent Western philosophy and science to the present day (Rescher $2000: 4$ ). In contrast, a process metaphysic treats change, rather than stasis, as fundamental (2000: 5). Processes develop over time and always have a "developmental, forward-looking aspect" (2000: 22). The salience of time is one compelling reason to explore this philosophy with regards to the Maya civilization, given its known preoccupation with time (e.g., Tedlock 1982; León-Portilla 1988; McLeod 2018).

Here I focus on the most influential of the twentieth-century thinkers, Alfred North Whitehead (1861-1947) (Rescher 1996: 20). Whitehead's metaphysic considers "becoming" as the ultimate characterization of "being" (e.g., Whitehead 1978). He was concerned with explaining the process of becoming, a process that accounts for both the distinction among various becomings-they are not all the same-and the historical aspects of becoming, whereby later becomings are predicated on those that happened earlier. Thus, existence has an "utterly relational character" (Halewood 2005: 63), and the passage of time as duration or accumulation is essential.

The superficial review of Whitehead's ideas provided here, based on Halewood's (2005) analysis, is intended to suggest a technical language or method to comprehend the ontology of Maya persons. I begin with Whitehead's notion of "eternal objects," although the word "object" may be misleading. These are the "pure potentials of the universe" that ingress (Whitehead's verb) into particular "becomings," forming "actual entities" by incarnating matter (2005: 72). These actual entities thereby account for the physical world. Importantly, in their "becoming" the actual entities "grasp their environment" in their specific context, resulting in differences among them despite a singular origin (2005: 63).

Furthermore, each becoming is shaped by the "extensive continuum." This continuum is an infinite relational complex that underlies the universe. It consists of all "actual entities" that have ceased "becoming." They are elements in the potential creation of new becomings that are shaped by prior becomings (Halewood 2005: 65-66). Although this continuum may seem "virtual" or always in potentia, it is nevertheless "real."

In sum, how new entities emerge or become actualized as differentiated matter is affected by "the environment" of their becoming, and also by the accumulated past becomings of earlier actual entities into which eternal objects have ingressed over time. Furthermore, processes are autopoietic, endowed with what Leibniz originally referred to as "appetition" or an inner compulsion to realize new features, resulting in never-ending change (Rescher 1996: 12, 21).

Thus, the universe is eventful, with pasts and futures distinguished from their presents even as they are interrelated by prior and future becomings (Halewood 2005: 74). This is an explanation for difference continually generated within an axiomatic ontological monism. Whitehead's process philosophy thus provides 
a polyvalent or "depth" ontology that accounts for the generation of new actual entities from virtual origins, rather than the monovalence that seems to trouble certain understandings of Mesoamerican monistic ontology.

Although this description of Whitehead's process metaphysic is very brief and abstract, his ideas can serve as a heuristic device for analyzing a general Maya ontology of personhood, especially how personhood is extended in space and time, within a processual model of reality but without defaulting to Aztec mechanisms of teotl as process.

\section{Personhood}

Importantly, twentieth-century anthropology had already moved precisely away from the Modern notion that the category of person is limited to static individual human beings. A person is a social and moral entity with capacities and responsibilities toward other entities with which it interacts. Any person is thus part of a larger whole and emerges (or becomes) out of relations with other parts of that whole. The works of Marilyn Strathern $(1988,1999)$ and others (e.g., Fortes 1973; Barraud 1990; Wagner 1991; Busby 1997; Mosko 1997; LiPuma 1998; Strathern and Lambek 1998; Fowler 2004, 2016; Santos-Granero 2009; Kairski 2018) have detailed how personhood is always in flux. It is fluid and relational, partible and plural, dependent at any moment on intrasubjective interactions in social fields with others. This ontology of personhood is thus compatible with the process metaphysic.

Many of these notions of personhood first appeared in essays by French sociologist Marcel Mauss (1872-1950) in 1929 (Mauss1969) and 1938 (Mauss 1985; see further explanation in Gillespie 2002, 2008a). His analysis of clan-based societies, such as the Zuni and Kwakiutl, along with the work of subsequent ethnographers (e.g., Kan 1989), revealed that each clan safeguarded a discrete set of names or titles as its property, which were distributed to living clan members. The names established the identities, positioning, rights, capacities, and destinies of individuals vis-à-vis others within the whole that was the clan.

In assuming one or more clan names during their lifetimes, individuals would actualize, in the material world, the virtual "prefigured totality of the life of the clan" (Mauss 1985: 5). This is a dialectical relationship played out as the ongoing "embodiment of persons and the personification of bodies" (Strathern and Lambek 1998: 6). Living individuals become the incarnations of ancestors of the same names, which is how the clan perpetuates itself across generations, assuring its continued existence (Mauss 1985: 8).

The actual clan "members" were thus the enduring names and titles (Kan 1989: 72), which Mauss (1985: 5) referred to as certain "characters" or personnages, each one a metonymic reference to the totality of the clan. The "person" as personnage is eternal, extended in time, and potential, always future-oriented. Different humans 
and even some non-human actors will temporarily embody a specific personnage, actualizing that potential in relation to one another and the totality of the clan, within a certain environment or socio-historical context. Upon their deaths, the names revert back to the clan for anticipated future generations.

History plays a role because names, titles, and other property could be gained through marriage alliance and also lost through warfare (Mauss 1985: 8; Weiner 1992: 37). Although the names are recycled, the embodied characters are impacted by the actions of prior holders of the same personnages. Thus, subsequent incarnations are not exactly the same as those who came before. Current situations and the accumulation of actions of continually "reincarnated" ancestors provided the specific "environments" for the emergence or "becoming" of newly embodied clan members, using Whitehead's terminology for the emergence of actual objects from an extensive continuum.

The existence of non-human persons had also been developed by Mauss in an earlier, 1925 seminal essay on the "gift" (Mauss 1954). Mauss showed that objects given in certain exchange relationships may represent, substitute for, or replace human persons. To give such objects away was to give part of oneself; indeed, the objects could be considered social persons in their own right (1954: 10). Over time the same person or personnage could be transformed back and forth between objects and humans.

This was especially the case for "inalienable" objects that, by definition, could not be estranged from their owners (Mauss 1954: 42). Many had their own names, titles, histories, and subjectivities. They were often retained as heirlooms that materialized the status and history of the clan that possessed them (Weiner 1992: 37). Many such objects were believed to have a "productive capacity" and to be animate replicas of a "never-ending supply" of prototypes endowed upon the clan ancestors by spirit beings (Mauss 1954: 43). As such they exist eternally virtually or in potentia, allowing them to be reinstantiated or actualized again in material form, rather like human persons.

Drawing inspiration from the ideas of Whitehead, which coincide well with the theorizing of the "person" by Mauss, I briefly survey various aspects of Maya personhood, specifically personhood centered on human beings. This review is presented in two parts. The first deals with how embodied persons are assembled and develop within their lifetimes in relation to other contemporaneous humans and also non-human objects and places. In these ways Maya persons are extended in space. The second part deals with the extension of eternal persons through time. This is merely an analytical distinction, however, given that in the Maya worldview, "space-time" forms a single dimension of reality. Nevertheless, the latter topic leads more directly into a Maya-centered mechanism of becoming within a process metaphysic, namely k'ex as substitution or replacement. 


\section{Assembling and Disassembling Maya Persons}

Applying these ontological principles to Maya personhood requires rejecting the Modern Western notion of the "individual" as a bounded, cohesive, moral and jural entity coinciding with a single human body and set in opposition to other individuals and to society (following, e.g., Strathern 1981: 168-169; La Fontaine 1985: 125). As the work of Mauss and other ethnographers revealed, personhood is relational and fluid (see, e.g., Fowler 2016), and need not be delimited to a single living human being. It is intrasubjectively constituted within various kinds of social fields and quasi-stable collectives, as parts of a larger whole. From the perspective of a process metaphysic, a particular person is "a megaprocess-a structured system of processes" unified through experience in time (Rescher 2000: 16, emphasis in original).

ThevariousfacetsofMaya, andmoregenerallyMesoamerican, personhoodincluding body, soul, and social position-have been well explored by scholars in diverse disciplines. These studies demonstrate possibilities for determining panMesoamerican or pan-Maya similarities as well as distinct differences (a small sample of this vast literature includes Vogt 1970; López Austin 1988; Furst 1995; Houston and Stuart 1998; Monaghan 1998; Gillespie 2001, 2002, 2008a, 2008b; Looper 2003; Houston et al. 2006; Bourdin 2007; Martínez González 2007; Page Pliego 2007-2008, 2014-2015; Pitarch 2011; Hendon 2012; Martínez González and Barona 2015). Here I similarly investigate general commonalities among Maya belief and practices, past and present, while recognizing diverse expressions and concepts within the Maya area itself.

From the most expansive, cosmological perspective each person is "a partial expression of humanity" and has obligations to all other beings (Monaghan 1998: 140). One manifestation of relational personhood proposed by John Monaghan (1998: 140) is how the Maya word for human being, winik, which also means 20, refers to the 20 day-names of the Mesoamerican ritual almanac by which the destiny of every human is entwined with specific cosmic forces and with all other persons.

From a sociological perspective, among the Maya and many other non-Modern complex societies, the principle corporate collective from which foundational aspects of personhood were derived was the intergenerational descent group known as the "house" (Gillespie 2000a, 2000b, 2001, 2011). Somewhat akin to clans and lineages, but with distinctive properties, the house was defined by Claude Lévi-Strauss (1982: 174) as a Maussian "moral person" in its own right-a corporate, plural person. The house provided its members with kinship positions and responsibilities, as well as names, titles, and tangible property, all of which it closely guarded. As such the house provided members with their identities and relationships to others, giving them a place within the social nexus, as well as a corresponding physical place-often the house as a dwelling-in the spatial network of the community. 
At the small scale of a particular embodied person, personhood is not automatic or inevitable. Its acquisition is the focus of a great deal of ritual and the actions of multiple other persons whose own identities and statuses are impacted by it (LaFontaine 1985: 132). Separate components, both physical and intangible, are conjoined and sometimes dissipated over a lifetime or beyond. In Maya belief and practice the assemblage - or "structured system of processes" following Rescher (2000: 16) - of a personified body begins at conception. Every human being combines diverse elements contributed by the father's and mother's houses. The bones, a dry enduring material, were contributed by the father manifesting the continuity of the patriline. The flesh or blood, a wet and perishable but life-giving substance that influenced one's well-being, was contributed by the mother's or wife-providing group (Gillespie and Joyce 1997: 199; Gillespie 2001). Rare images of Maya kings showing them with both parents, such as Palenque's Palace Tablet, are not family portraits-and the parents in this case were deceased-but are embodied depictions of separable components of the king's person endowed by parental houses (Gillespie and Joyce 1997: 202; Gillespie 2008a).

In addition to physical components, the embodied person assembles certain intangible elements, including names or titles, which may themselves contain a vital essence (e.g., Montagu and Hunt 1962: 146). They are also endowed with life-giving animistic energies (e.g., López-Austin 1988: 181) and one or more "souls," frequently including animal "souls" or companion spirits (e.g., Vogt 1969: 372; 1970: 1155; cf. Bourdin 2007-2008). Finally, there is a near-universal belief among Maya peoples in an eternal soul that pre-exists and survives a specific human being. Frequently names are linked to this soul "as a package" (Vogt 1970: 1158; see Guiteras-Holmes 1961: 110), sometimes transmitted through the patriline (Montagu and Hunt 1962: 141; Vogt 1969: 372, 1970: 1158).

Among the contemporary Tzotzil and Tzeltal Maya of Chiapas, for example, this personal soul was known as chiulel (Vogt 1969; Pitarch 1996). It was believed to be placed in the body at conception. It departs the body at death and ultimately rejoins the "pool" of souls kept by the ancestral deities, to be put in the embryo of a newly conceived child (Vogt 1969: 370). A similar belief in the rejoining of disembodied souls in a kind of eternal continuum was expressed by Yucatec and highland Maya peoples (Redfield and Villa Rojas 1934: 199; Carmack 1981: 150). Suggestive evidence for souls in prehispanic inscriptions includes the way glyph as a kind of "co-essence" (Houston and Stuart 1989) and a "death event" read as "the diminution of the sak-nik-nal," the "white-flower-thing" (Freidel et al. 1993: 183).

These examples illustrate how decease requires rituals of disassembly of the components of embodied persons assembled in life. This is a dual process: the decomposition of the biological being coincides somewhat with dissolution of the social person (Mauss's personnage), involving a biological decease and a distinctly 
commemorated social death (Gluckman 1937: 118; Hertz 1960). The mortal and immortal components of the personified body are separated and destined for different dispositions, including curation for future use. For example, the Yucatec Maya would open a hole in a thatch roof directly above a dying person's hammock to assure free passage of the soul upon death; newer houses used a small window near the ceiling for the same purpose (Redfield and Villa Rojas 1934: 199).

Archaeological data from Classic Maya sites such as Palenque, Mexico, and Caracol, Belize, indicate that bodies were subjected to several stages of processing in different locales before their final disposition. These include "empty" tombs used for stages of bodily decomposition, and curated skeletal parts sometimes actively used by the living (e.g., Welsh 1988: 193, 216; Chase and Chase 1996: 76, 1998: 311). There are also ethnohistoric descriptions of similar practices (e.g., Landa 1982: 59). Hieroglyphic inscriptions provide information on a sequence of secondary funerary and commemorative rituals in the Classic Period (Stuart 1998: 396-398; Cucina et al. 2004: 74;). Patricia McAnany (1998: 289) suggested that the event read as muknal, which may occur even dozens of years after biological decease, marked the final "social death," what is referred to in similar contexts elsewhere as "the end of a person" (Kan 1989: 181-182; Barraud 1990: 224). Nevertheless, even after death body and soul maintained a relationship with one another. Bodies or body parts were curated by the families of the dead in order to ensure that their eternal souls would eventually enter the embryos of children subsequently born in that house, as a way of safeguarding the house's intangible property (e.g., Thompson 1930: 82; see Gillespie 2002).

\section{The Extended Person in Space}

As Marcel Mauss (1954: 10) demonstrated, people could extend their personhood beyond their bodies and into non-human entities, the "gift-like" inalienable objects. Among the prehispanic Maya some of the best information for such objects are well-made items used in intimate proximity to embodied persons, worn or manipulated by them. Many of these fine objects were "nametagged" (Houston and Taube 1987) with the names or titles of their owners, as part of the inalienable property of wealthy or aristocratic houses. Rosemary Joyce (2000) observed that these were often deposited in graves or other caches long after their initial creation, and sometimes far away, as they were moved through exchange networks. Thus, the person(s) they referenced and the houses that claimed them as members were extended in space.

Rulers, however, had a special status. Among other things, they were already touched by the divine, monopolizing the title of kuhul ajaw, "divine lord" (e.g., Houston and Stuart 1996). Rulers or close family members could also create separable manifestations of their being in the form of images or icons of themselves 
(Houston and Stuart 1998: 81; Looper 2003: 28; Houston et al. 2006: 72-74;). Stephen Houston and David Stuart (1998: 86) suggested there was "an extendable essence shared between images" and the portrayed person, such that these "portraits contained part of the royal essence, in ways that multiplied his presence" in different places, even beyond death (1998: 90).

Putting these two contexts together: When intimate, inalienable costume objects were depicted on royal bodies, the rulers themselves became a human framework for materializing the history and prestige of their royal house. Late Preclassic and Early Classic images especially show royal bodies laden with animated objects (e.g., Tikal Stela 29, AD 292). Indeed, it is as if the king's body was composed primarily of these vitalizing sacred objects-heirlooms of the royal house and other signs of rank or title. Only facial features and glimpses of appendages serve as minimal reference points to his bodily presence (Gillespie 2008b).

In these images the king thereby becomes an icon and index of the history, identity, and rank of the royal house. He further assembles the totality of his polity within himself, extending his person outward to the periphery of his political aegis. In this respect, the ruler is a "plural person" in Marilyn Strathern's (1988: 15) terminology, incorporating other persons within his own. He becomes the whole out of which persons of a lesser order, less complete by comparison, realize their own agency and capabilities in relationship to him (Gillespie 2008b).

In addition to the tangible entities such as inalienable objects and royal images, persons assembled extra-bodily intangible extensions during their lifetimes. Inherited names, acquired as members of established houses, have already been mentioned, but names and titles could also be won or lost in warfare (Mauss 1985: 8-9). There are known instances in Maya iconography in which named war captives are shown with their titles-and thus much of their person-usurped by their captor, such as Bird Jaguar IV on Yaxchilan Lintel 8 (Schele and Freidel 1990: 143, 295-297). These kings thereby further extended their own plural persons beyond the boundaries of their political domains.

The transfer of personified names across generations is also known from Classic period iconography and epigraphy. Especially in the western Maya lowlands, reconstructions of king lists reveal multiple rulers in a single royal house with the same name. For example, at Yaxchilan, Mexico, there were at least four rulers named Bird Jaguar (Tate 1992: 9), and at Palenque, two named Pakal (Schele and Freidel 1990: 222). This enchainment of persons through a dynastic line reveals how each successive name-holder "actualizes" a name and associated status that ultimately belongs to the royal house. It is ostensibly eternal, moving back and forth between a continuum of virtual potentiality and the historically specific living appropriators of that name and person. This sequence manifests the extension of Maya persons in time-the "durational person" - which is the final topic. 


\section{The Extended Person in Time: Substitution and Replacement}

The extension of persons in time has already been referenced with the dialectical movement of souls between incarnation in a new human being and return to a continuum or "pool" of souls upon decease. However, these former incarnations of souls were not necessarily forgotten. Instead, with appropriate rituals, they became ancestors, intangible instantiations of persons with whom the living continued to interact. There is a plethora of archaeological evidence for ancestor veneration practices among the Maya (e.g., Welsh 1988: 186-193; McAnany 1995, 1998; Gillespie 2000b) congruent with ethnohistoric (Las Casas 1967:2: 526; Landa 1982: 59) and some ethnographic accounts (e.g., Vogt 1969: 298-301; Nash 1970: 22; Watanabe 1990: 139-141, 1992). Shrines, images, and altars were and still are used to interact with ancestors. Significantly, their bodily remains may have served to attract their spirits as a means for maintaining their souls within the control of the social house, which, as already noted, helps to explain residential burial practices (see Gillespie 2002).

Furthermore, as remarked above, names and souls may move "as a package." Many contemporary Maya peoples believe that souls are reincarnated in subsequently born family members given the same name, such that both name-holders share in important aspects of their identities (e.g., Thompson 1930: 82; Guiteras-Holmes 1961: 110; Montagu and Hunt 1962: 141; Vogt 1969: 372, 1970: 1158; Watanabe 1990: 139; Carlsen and Prechtel 1991: 26-29). The persons of the ancestors live again in their same-named descendants, having achieved thereby immortality (Carlsen and Prechtel 1991: 26). In many Maya societies grandchildren are given the names of their grandparents. When the older person and the younger relative of the same name are both alive, they are thought to share the same vital essence. However, in some cases infants are not given the name of a living family member because it is believed that they would thereby fully acquire the soul of the older relative, causing that individual's premature death (Montagu and Hunt 1962: 144). More generally, beyond the transmission of specific names and souls, in many Maya languages grandparent and grandchild mutually refer to one another by the same kin term: mam.

These practices and beliefs exemplify a more encompassing process, a specific mode of continuous change expressed in Maya languages as k'exol and cognates, including jelol (Montagu and Hunt 1962: 141) and caxel (Earle 1986: 162; see Watanabe 1990: 139). Dictionary definitions translate the verbal form as exchange, trade, to take one's place or convert one thing to another (e.g., Laughlin 1975: 191; Barrera Vásquez 1980: 397;), and the noun form refers to substitute or replacement (Vogt 1970: 1158). Redfield and Villa Rojas (1934: 174) discussed k'ex in Yucatan as an offering of maize gruel in "promise" or pre-payment to malevolent spirits causing sickness. Karl Taube (1994) analyzed k'ex in a similar context of 
human and animal sacrifice in the prehispanic era, with the sacrificial victim acting as the substitute, even the payment, for the ritual officiant on whose behalf the sacrifice was made.

In an influential study Robert Carlsen and Martin Prechtel (1991) provided a general description of k'exoj as a kind of change that is a transfer from one entity to another, "making the new out of the old" (1991 :26). Grandchildren "replace" or "substitute" for their grandparents, as their grandparents did before them, which is one reason why they mutually refer to each other as mam. Name repetition across generations of Maya grandparents and grandchildren exemplifies a specific form of "genealogical" (Montagu and Hunt 1962: 144) or "generational" replacement (Carlsen and Prechtel 1991: 26). The same kind of replacement is evident in the name repetition in royal houses of Palenque and Yaxchilan described above.

However, further to the east, at Classic Period Tikal, Guatemala (Jones 1991: 109) and Copan, Honduras (Schele and Freidel 1990: 331), continuity of the rulers as heads of the royal house was indicated instead by numerically marking one's position in a line of succession back to the putative founder, rather than name sharing. This is referred to as "positional replacement" (Montagu and Hunt 1962) and is a different means to emphasize the enchainment of persons across generations. Altar Q at Copan (Schele and Freidel 1990:328; Martin and Grube 2000:210) is a striking example of the implications of this practice. It was erected by the sixteenth successor of the dynastic founder and shows him with all 15 of his predecessors, four arrayed on each side of the square altar, facing the founderwho directly hands him instruments of office. It indicates the simultaneity of these sixteen individuals in sharing the personnage of k'uhul ajaw of Copan, even as that personnage was incarnated in a historical chain of human beings, each of whom contributed to its accumulating status.

K'ex as positional replacement also survives today in the common practice among cofradía or cargo holders, who usually hold office for one year or a similar specific term and are succeeded by their replacements (e.g., Cancian 1965). The ceremony for the new office-holders is called kexeltik in Tzotzil Maya (GuiterasHolmes 1961: 88), and the new office-holder is addressed as kexolil ("successor") by his immediate predecessor (Laughlin 1975: 191; see Montagu and Hunt 1962: 142).

A number of ethnographers have mentioned the prevalence and manifestations of k'ex as substitution or replacement, and it has been called "a central paradigm of the local culture" of Santiago Atitlan by Carlsen and Prechtel (1991:25). Nevertheless, I believe it warrants further recognition. K'ex operates as a principal mode of a processual Maya ontology of becoming, of emergence as transference, as one phenomenon is literally replaced or succeeded by another. In another context, Stephen Houston $(2014: 29,72)$ suggested that due to kex, even raw substances such as flint or obsidian were not stable but "stood ready to change from one thing to another," such that "[t]ruly new things may not exist." In short, k'ex appears to be an 
impulse or drive, another mode of Leibnitzian appetition that endows reality with constant flux. However, it is quite different from the "agonistic inamic unity" that Maffie (2014: 137) suggested characterized Aztec teotl as a process, especially because change and difference are inevitable outcomes, making k'ex forward-looking.

\section{“Replacement" as Critical to Time and Cosmic Creation}

K'ex as a manifestation of a fundamental mechanism of process in Maya ontology also complements what is already known about Maya notions of time, which are also different from their Aztec counterparts. J. Eric Thompson (1960: 141) envisioned the Maya scheme of time as an endless road that stretched infinitely into the remote past even as it also led into an infinite future. It was an extensive continuum composed of previous, perished time periods which continuously ingressed into individual tuns (years) in unceasing sequence.

Importantly, replacement is not the same as cloning or duplication. This is not the stereotype of unchanging cyclical time. What transpires in any instantiation of an eternal object will impact it as it rejoins an extensive continuum, providing an innovated context or environment for subsequent realizations of eternal objects. As Tedlock (1982: 176) put it, for the Maya, time "accumulates": "no given time, whether past, present, or future, can ever be totally isolated from the segments of time that precede or follow it." Interestingly, the sequential change of time periods was accommodated by an overlap between the outgoing and incoming periods, what Tedlock (1982: 177) called an "imbrication," as opposed to a hard boundary and instantaneous transition. Friar Diego de Landa's (1982: 63-65) sixteenthcentury description of a "new year's" ceremony in Yucatan, requiring two images to be venerated during the brief interval between the old and new year, seems to manifest the same concern for overlap, with the successor primed to take the place when the predecessor's term was over. The replacement year was in position, and its assumption of that status was inevitable.

Finally, a few Maya scholars have observed a similar phenomenon of substitution or replacement in cosmogonic accounts that narrate the creation of the cosmos. Such narratives should be especially fraught with attention to ontological issues, given that they relate the nature of cosmic being and how it came about. Thus, for example, in the Popol Vuh (Tedlock 1996) of the colonial K'iche' Maya, the twin heroes Hunahpu and Xbalanke were conceived by the spittle-kexaj-ejected from the skull (bone) of their father into the hand of their mother, Xkik ("Blood"), an intentional play on words to signify replacement (Carlsen and Prechtel 1991: 31). More generally, the successive creations and destructions of humans by the gods in this epic narrative reveal legacies or traces of earlier events in later episodes (Tedlock 1982: 177). Nathaniel Tarn and Martin Prechtel (1981: 105-107) further commented on the "great many redundancies, repetitions, [and] overlaps" of similar 
characters-Maussian personnages -from one episode to the next, and suggested they were structural "transforms" of one another, in a logical, or Lévi-Straussian sense.

However, in the Maya worldview they should actually be ontologically connected transforms of one another. This is the operation of kex as replacement -in this case, differentiated manifestations of recurrent beings, places, and objectsat a far larger scale. The story engages a dynamic dialectic between predecessor and successor, a process that fatefully moves the universe forward, as Tarn and Prechtel (1981: 121) also recognized. Indeed, the failure to appreciate this fundamental process has resulted in certain misunderstandings of the Popol Vuh. In particular, it is commonly believed that certain episodes are out of order because the boy heroes appear in several episodes before the narrator relates their conception and birth (e.g., Tedlock 1996: 43; see Gillespie 2013, 2019). However, this interpretation assumes the Modern notion of the singular and static individual, rather than the successions and replacements of personnages in Maya ontology, including the different, sequential appearances of the characters named Hunahpu and Xbalanke.

\section{Conclusion}

This brief survey of information on the construction and extension of Maya persons reveals constant becomings throughout (and even beyond) individual lives. The actualization of Maya persons puts into practice the principal concepts and processes axiomatic of Maya ontology and metaphysics. In particular, the fundamental process known as kex accounts for the flux and duration of the universe in a way that is distinct from Aztec notions of teotl while still consistent with Mesoamerican ontological monism. Adopting an encompassing process metaphysic, in this case utilizing the model outlined by Alfred North Whitehead, provides a technical language for analyzing the extension of Maya persons in space and time. It is also concordant with the fluid and intrasubjective concept of the "person" developed by Mauss and later ethnographers that is consonant with the Maya evidence.

Numerous Maya practices and beliefs that manifest a concern for continuity across generations or time periods become more sensible as contributing to a larger pattern of cosmic operation. Time is central to this ontology. It is historicized, its accumulation dependent on both the reincarnation of virtual persons as they become actualized, as well as the processual changes they incur in their lifetimes that feed back into a complex, eternal "extensive continuum." Past and future are thereby imbricated rather than separated.

Finally, archaeologists can be alert to the different kinds of persons who inhabited and made historical differences in Maya societies, along with their material manifestations, that is to say, their "traces" (Joyce 2012). They can attempt to read the traces of past actualizations that influenced subsequent ones, as an enchainment 
of persons (human and non-human) over time. They can also take into account how ancient Maya peoples themselves looked for material legacies of the past in their present as they anticipated their futures.

\section{Acknowledgments}

An earlier version of this paper was presented at the Third Warsaw Maya Meeting on "The Essence of Life and Ontology in the Maya World" in May 2021. I gratefully acknowledge the kind invitation by the organizers-Stanisław Iwaniszewski, Agnieszka Hamann, and Michał Gilewski-to present my ideas as well as the scholarly interactions with the other participants. I also acknowledge the helpful comments provided by an anonymous reviewer to improve the manuscript. The Spanish translation of the abstract was prepared by Jordi Armani Rivera Prince.

\section{References}

Alberti, Benjamin

2016 Archaeologies of ontology. Annual Review of Anthropology 45 (1): 163-179. https:// doi.org/10.1146/annurev-anthro-102215-095858

Alberti, Benjamin, and Tamara L. Bray

2009 Introduction. Animating archaeology: Of subjects, objects, and alternative ontologies. Cambridge Archaeological Journal 19 (3): 337-343. https://doi.org/10.1017/ S0959774309000523

Alberti, Benjamin, Severin Fowles, Martin Holbraad, Yvonne Marshall, and Christopher Witmore

2011 "Worlds otherwise": Archaeology, anthropology, and ontological differences. Current Anthropology 52 (6) :896-912. https://doi.org/10.1086/662027

Barraud, Cécile

1990 Kei society and the person: An approach through childbirth and funerary rituals. Ethnos 55 :214-231.

Barrera Vásquez, A., Alfredo, Juan Ramón Bastarrachea Manzano, William Brito Sansores, Refugio Vermont Salas, David Dzul Góngora, and Domingo Dzul Poot

1980 Diccionario maya Cordemex. maya-español, español-maya. Ediciones Cordemex, Merida, Mexico.

Bourdin, Gabriel Luis

2007 La noción de persona entre los mayas: Una visión semántica. Revista pueblos y fronteras digital Vol. 2(4). Universidad Nacional Autónoma de México. https://doi.org/10.22201/cimsur.18704115e.2007.4.218

Browning, Douglas (editor)

1965 Philosophers of process. Random House, New York.

Burkhart, Louise M.

1989 The slippery earth: Nahua-Christian moral dialog in sixteenth-century Mexico. University of Arizona Press, Tucson, Arizona. 
Busby, Cecilia

1997 Permeable and partible persons: A comparative analysis of gender and the body in South India and Melanesia. Journal of the Royal Anthropological Institute 3 (2) :261-278. https://doi.org/10.2307/3035019

Cancian, Frank

1965 Economics and prestige in a Maya community: The religious cargo system in Zinacantan. Stanford University Press, Stanford, California.

Carmack, Robert M

1981 The Quiché Mayas of Utatlán: The evolution of a highland Guatemala kingdom. University of Oklahoma Press, Norman, Oklahoma.

Carlsen, Robert, and Martin Prechtel

1991 The flowering of the dead: An interpretation of highland Maya culture. Man 26 (1): 23-42. https://doi.org/10.2307/2803473

Chase, Diane Z., and Arlen F. Chase

1996 Maya multiples: Individuals, entries, and tombs in Structure A34 of Caracol, Belize. Latin American Antiquity 7 (1): 61-79. https://doi.org/10.2307/3537015

1998 The architectural context of caches, burials, and other ritual activities for the Classic period Maya. In Function and meaning in classic Maya architecture, edited by Stephen Houston, pp. 299-332. Dumbarton Oaks Research Library \& Collection, Washington, D. C.

Coole, Diana, and Samantha Frost

2010 New materialisms: Ontology, agency, and politics. Duke University Press, Durham, North Carolina.

Cucina, Andrea, Vera Tiesler Blos, and Arturo Romano Pacheco

2004 Los acompañantes de Janaab’ Pakal y de la “Reina Roja” de Palenque, Chiapas. El significado de sacrificios humanos en las exequias de la sociedad maya del clásico. In Janaab' Pakal de Palenque: Vida y muerte de un gobernante maya, edited by Vera Tiesler Blos and Andrea Cucina, pp. 69-102. Universidad Nacional Autónoma de México/Universidad Autónoma de Yucatán, Mexico City.

DeLanda, Manuel

2006 A new philosophy of society: Assemblage theory and social complexity. Continuum, London.

Descola, Philippe

2013 Beyond nature and culture [translation by Janet Lloyd]. University of Chicago

Earle, Duncan Press, Chicago, Illinois.

1986 The metaphor of the day in Quiche: Notes on the nature of everyday life. In Symbol and meaning beyond the closed community: Essays in Mesoamerican ideas, edited by Gary Gossen, pp. 155-172. Institute for Mesoamerican Studies, State University of New York, Albany, New York.

Fortes, Meyer

1973 On the concept of the person among the Tallensi. In La notion de personne en Afrique noire, edited by Germaine Dieterlen, pp. 283-319. Éditions du Centre National de la Recherche Scientifique, Paris.

Fowler, Chris

2004 The archaeology of personhood: An anthropological approach. Routledge, London. 
2016 Relational personhood revisited. Cambridge Archaeological Journal 26(3):397-412. https://doi.org/10.1017/S0959774316000172

Freidel, David, Linda Schele, and Joy Parker

1993 Maya cosmos: Three thousand years on the shaman's path. William Morrow, New York.

Furst, Jill Leslie McKeever

1995 The Natural History of the Soul in Ancient Mexico. Yale University Press, New Haven, Connecticut.

Gell, Alfred

1998 Art and agency: An anthropological theory. Clarendon, Oxford, United Kingdom.

Gillespie, Susan D.

2000a Maya "nested houses": The ritual construction of place. In Beyond kinship: social and material reproduction in house societies, edited by Rosemary A. Joyce and Susan D. Gillespie, pp. 135-160. University of Pennsylvania Press, Philadelphia, Pennsylvania.

2000b Rethinking ancient Maya social organization: Replacing "lineage" with "house." American Anthropologist 102 (3): 467-484. https://doi.org/10.1525/ aa.2000.102.3.467

2001 Personhood, agency, and mortuary ritual: A case study from the ancient Maya. Journal of Anthropological Archaeology 20 (1): 73-112. https://doi.org/10.1006/ jaar.2000.036

2002 Body and soul among the Maya: Keeping the spirits in place. In The space and place of death, edited by Helaine Silverman and David Small. Archeological Papers of the American Anthropological Association, No. 11, pp. 67-78.

2008a Aspectos corporativos de la persona (personhood) y la encarnación (embodiment) entre los Mayas del periodo clásico. Estudios de Cultura Maya 31: 55-89. https:// doi.org/10.19130/iifl.ecm.2008.31.633

2008b Embodied persons and heroic kings in Late Classic Maya sculpture. In Past bodies: Body-centred research in archaeology, edited by Dušan Borić and John E. Robb, pp. 125-134. Oxbow books, Oxford, United Kingdom.

2011 El modelo de la "casa" en la estructura política maya. In El despligue del poder entre los Mayas: Nuevos estudios sobre la organización política, edited by Ana Luisa Izquierdo, pp. 29-61. Universidad Nacional Autónoma de México, Mexico City.

2013 Gendering the hero twins in the Popol Vuh. In Género y arqueología en Mesoamérica: Homenaje a Rosemary A. Joyce, edited by María J. Rodríguez-Shadow and Susan Kellogg, pp. 139-151. Centro de Estudios de Antropología de la Mujer, Mexico City.

2019 The Popol Vuh: A new English version, translated from the K'iche' by Michael Bazzett. Delos: A Journal of Translation and World Literature 34 (2): 285-290. https:// doi.org/10.5744/delos.2019.1028

Gillespie, Susan D., and Rosemary A. Joyce

1997 Gendered goods: The symbolism of Maya hierarchical exchange relations. In Women in prehistory: North America and Mesoamerica, edited by Cheryl Claassen and Rosemary A. Joyce, pp. 189-207. University of Pennsylvania Press, Philadelphia, Pennsylvania. 
Gluckman, Max

1937 Mortuary customs and the belief in survival after death among the South-Eastern Bantu. Bantu Studies 11: 117-136.

Gosden, Chris, and Lambros Malafouris

2015 Process archaeology (P-Arch). World Archaeology 47(5):701-717. https://doi.org/1 0.1080/00438243.2015.1078741

Guiteras-Holmes, Calixta

1961 Perils of the soul: The world view of a Tzotzil indian. The Free Press of Glencoe, New York.

Halewood, Michael

2005 On Whitehead and Deleuze: The process of materiality. Configurations 13 (1): 57 76.

Harman, Graham

2008 DeLanda's ontology: Assemblage and realism. Continental Philosophy Review 41 (3): 367-383. https://doi.org/10.1007/s11007-008-9084-7

Harrison-Buck, Eleanor, and Julia A. Hendon (editors)

2018 Relational identities and other-than-human agency in archaeology. University Press of Colorado, Louisville, Colorado.

Hendon, Julia A.

2012 Objects as persons: Integrating maya beliefs and anthropological theory. In Power and identity in archaeological theory and practice: Case studies from ancient Mesoamerica, edited by Eleanor Harrison-Buck, pp. 82-89. University of Utah Press, Salt Lake City, Utah.

Hertz, Robert

1960 A contribution to the study of the collective representation of death. In Death and the right hand, edited by Rodney Needham and Claudia Needham, pp. 27-86. The Free Press, Glencoe, Illinois.

Houston, Stephen

2014 The life within: Classic Maya and the matter of permanence. Yale University Press, New Haven, Connecticut.

Houston, Stephen, and Karl A. Taube

1987 Name-tagging in classic Mayan script. Mexicon 9 (2): 38-41. http://www.jstor.org/stable/23758686

Houston, Stephen, and David Stuart

1989 The way glyph: Evidence for co-essences among the classic Maya. Research Reports in Classic Maya Writing 30. Center for Maya Research, Washington, D. C.

1996 Of gods, glyphs and kings: Divinity and rulership among the classic Maya. Antiquity 70 (268): 289-312.

1998 The ancient Maya self: Personhood and portraiture in the Classic period. Res: Anthropology and Aesthetics 33: 73-101.

Houston, Stephen, David Stuart, and Karl A. Taube

2006 The memory of bones: Body, being, and experience among the Classic Maya. Univer-

Hunt, Eva sity of Texas Press, Austin, Texas.

1977 The transformation of the hummingbird: Cultural roots of a Zinacantecan mythical poem. Cornell University Press, Ithaca, New York. 
Hvidtfeldt, Arild

1958 Teotl and ixiptlatli: Some central conceptions in ancient Mexican religion, with a general introduction on cult and myth. Munksgaard, Copenhagen, Denmark.

Jones, Christopher

1991 Cycles of growth at Tikal. In Classic Maya political history: Hieroglyphs and archaeological evidence, edited by T. Patrick Culbert, pp. 102-127. Cambridge University Press, Cambridge, United Kingdom.

Joyce, Rosemary A.

2000 Heirlooms and houses: Materiality and social memory. In Beyond kinship: Social and material reproduction in house societies, edited by Rosemary A. Joyce and Susan D. Gillespie, pp.189-212. University of Pennsylvania Press, Philadelphia, Pennsylvania.

2012 Life with things: Archaeology and materiality. In Archaeology and anthropology: Past, present and future, edited by David P. Shankland, pp. 119-132. Berg, Oxford, United Kingdom.

2015 History and materiality. In Emerging trends in the social and behavioral sciences, edited by Robert Scott and Stephan Kosslyn. John Wiley \& Sons, Hoboken, New Jersey.

Kairski, Mariusz

2018 La persona y su identidad en la Amazonía: Problemas básicos. Estudios Latinoamericanos 38: 173-186. https://doi.org/10.36447/Estudios2018.v38.art9

Kan, Sergei

1989 Symbolic immortality: The Tlingit potlatch of the nineteenth century. Smithsonian Institution Press, Washington, D. C.

Klor de Alva, J. Jorge

1979 Christianity and the Aztecs. San Jose Studies 5: 6-21.

Kosiba, Steve, John W. Janusek, and Thomas B. F. Cummins (editors)

2020 Sacred matter: Animacy and authority in the Americas. Dumbarton Oaks Research Library \& Collection, Washington, D. C.

La Fontaine, J. S.

1985 Person and individual: Some anthropological reflections. In The category of the person: Anthropology, philosophy, history, edited by Michael Carrithers, Stephen Collins, and Steven Lukes, pp. 123-140. Cambridge University Press, Cambridge, United Kingdom.

Landa, Friar Diego de

1982 Relación de las cosas de Yucatán. 12 ${ }^{\text {th }}$ edition. Editorial Porrúa, Mexico City.

Las Casas, Friar Bartolomé de

1967 Apologética historia sumaria, edited by Edmundo O'Gorman, $3^{\text {rd }}$ edition. 2 volumes. Universidad Nacional Autónoma de México, Mexico City.

Latour, Bruno

2005 Reassembling the social: An introduction to actor-network-theory. Oxford University Press, Oxford, United Kingdom.

Laughlin, Robert M.

1975 The great Tzotzil dictionary of San Lorenzo Zinacantán. Smithsonian Contributions to Anthropology No. 19. Smithsonian Institution Press, Washington, D. C. 
León-Portilla, Miguel

1988 Time and reality in the thought of the Maya [translation by Charles L. Boilès, Fernando Horcasitas, and the Author]. $2^{\text {nd }}$ edition. University of Oklahoma Press, Norman, Oklahoma.

Lévi-Strauss, Claude

1982 The way of the masks [translation by Sylvia Modelski]. University of Washington Press, Seattle, Washington.

LiPuma, Edward

1998 Modernity and forms of personhood in Melanesia, In Bodies and persons: Comparative perspectives from Africa and Melanesia, edited by Michael Lambek and Andrew Strathern, pp. 53-79. Cambridge University Press, Cambridge, United Kingdom.

Looper, Matthew

2003 From inscribed bodies to distributed persons: Contextualizing Tairona figural images in performance. Cambridge Archaeological Journal 13 (1): 25-40. https://doi. org/10.1017/S0959774303000027

López Austin, Alfredo

1988 The human body and ideology: Concepts of the ancient Nahuas [translation by Thelma Ortiz de Montellano and Bernard Ortiz de Montellano]. Volume 1. University of Utah Press, Salt Lake City, Utah.

McAnany, Patricia A.

1995 Living with the ancestors: Kinship and kingship in ancient Maya society. University of Texas Press, Austin, Texas.

1998 Ancestors and the Classic Maya built environment. In Function and meaning in Classic Maya architecture, edited by Stephen Houston, pp. 271-298. Dumbarton Oaks Research Library \& Collection, Washington, D. C.

McLeod, Alexus

2017 Philosophy of the ancient Maya: Lords of time. Lexington Books, Lanham, Maryland.

Maffie, James

2014 Aztec philosophy: Understanding a world in motion. University Press of Colorado, Boulder, Colorado.

Martin, Simon, and Nikolai Grube

2000 Chronicle of Maya kings and queens: Deciphering the dynasties of the ancient Maya. Thames \& Hudson, London.

Martínez González, Roberto

2007 El alma de Mesoamérica: Unidad y especificidad en las concepciones anímicas de sus indígenas, Journal de la Société des Américanistes, 93(2): 7-49. www.jstor.org/stable/24606372

Martínez González, Roberto, and Carlos Barona

2015 La noción de persona en Mesoamérica: Un diálogo de perspectivas. Anales de Antropología 49(2): 13-72.

Mauss, Marcel

1954 The gift: Forms and functions of exchange in archaic societies [translation by Ian Cunnison]. Cohen and West, London.

1969 Lâme, le nom et la personne. Oeuvres 2: 131-143. Minuit, Paris. 
1985 A category of the human mind: The notion of person, the notion of self [translation by W. D. Halls]. In The category of the person: Anthropology, philosophy, history, edited by Michael Carrithers, Stephen Collins, and Steven Lukes, pp. 1-25. Cambridge University Press, Cambridge, United Kingdom.

Monaghan, John D.

1998 The person, destiny, and the construction of difference in Mesoamerica. Res: Anthropology and Aesthetics 33: 137-146.

2000 Theology and history in the study of Mesoamerican religions. In Supplement to the handbook of Middle American Indians, edited by Victoria Reifler Bricker, Volume 6, Ethnology, edited by John D. Monaghan, pp. 24-49. University of Texas Press, Austin, Texas.

Montagu, Roberta, and Eva Hunt

1962 Nombre, autoridad y el sistema de creencias en los altos de Chiapas. Estudios de Cultura Maya 2: 141-147. https://doi.org/10.19130/iifl.ecm.1962.2.216

Mosko, Mark S.

1992 Motherless sons: "Divine kings" and "partible persons" in Melanesia and Polynesia. Man 27 (4): 697-717. London. https://doi.org/10.2307/2804170

Nash, June

1970 In the eyes of the ancestors: Belief and behavior in a Maya community. Yale University Press, New Haven, Connecticut.

Page Pliego, Jaime Tomás

2014-2015 La importancia del cuerpo en la noción de persona entre mayas actuales de Oxchuc, Chamula y Chenalhó, Chiapas. Revista pueblos y fronteras digital 9(18): 35-48. Universidad Nacional Autónoma de México. https://doi.org/10.22201/ cimsur.18704115e.2014.18.21

Page Pliego, Jaime Tomás, Coordinator

2007-2008 La noción de persona en México y Centroamérica. Revista pueblos y fronteras digital, Vol.2 (4). Universidad Nacional Autónoma de México. https://doi. org/10.22201/cimsur.18704115e.2007.4.215

Pitarch, Ramón Pedro

1996 Ch’ulel: Una etnografía de las almas tzeltales. Fondo de Cultura Económica, Mexico City.

2011 Los dos cuerpos mayas. Esbozo de una antropología elemental indígena. Estudios de Cultura Maya 37: 151-178. https://doi.org/10.19130/iifl.ecm.2011.37.17

Redfield, Robert, and Alfonso Villa Rojas

1934 Chan Kom: A Maya village. University of Chicago Press, Chicago.

Rescher, Nicholas

1996 Process metaphysics: An introduction to process philosophy. State University of New York Press, Albany, New York.

2000 Process philosophy: A survey of basic issues. University of Pittsburgh Press, Pittsburgh, Pennsylvania.

Robb, John

2010 Beyond agency. World Archaeology 42 (4): 493-520. https://doi.org/10.1080/00438 243.2010.520856 
Santos-Granero, Fernando

2009 Introduction: Amerindian constructional views of the world. In The occult life of things: Native Amazonian theories of materiality and personhood, edited by Fernando Santos-Granero, pp. 1-29. University of Arizona Press, Tucson, Arizona.

Schele, Linda, and David A. Freidel

1990 A forest of kings: The untold story of the ancient Maya. William Morrow, New York.

Strathern, Andrew, and Michael Lambek

1998 Introduction: Embodying sociality: Africanist-Melanesianist comparisons. In Bodies and persons: Comparative perspectives from Africa and Melanesia, edited by Michael Lambek and Andrew Strathern, pp. 1-25. Cambridge University Press, Cambridge, United Kingdom.

Strathern, Marilyn

1981 Self-interest and the social good: Some implications of Hagen gender imagery. In Sexual meanings: The cultural construction of gender and sexuality, edited by Sherry B. Ortner and Harriet Whitehead, pp. 166-191. Cambridge University Press, Cambridge, United Kingdom.

1988 The gender of the gift: Problems with women and problems with society in Melanesia. University of California Press, Berkeley, California.

1999 Property, substance and effect: Anthropological essays on persons and things. Athlone, London.

Stuart, David

1998 "The fire enters his house": Architecture and ritual in Classic Maya texts, In Function and meaning in Classic Maya architecture, edited by Stephen Houston, pp. 373425. Dumbarton Oaks Research Library \& Collection, Washington, D. C.

Tarn, Nathaniel, and Martin Prechtel

1981 Metaphors of relative elevation, position and ranking in Popol Vuh. Estudios de Cultura Maya 13: 105-123. https://doi.org/10.19130/iifl.ecm.1981.13.537

Tate, Carolyn E.

1992 Yaxchilan: The design of a Maya ceremonial city. University of Texas Press, Austin.

Taube, Karl A.

1994 The birth vase: Natal imagery in ancient Maya myth and ritual. In The Maya vase book: A corpus of rollout photographs of Maya vases, by Justin Kerr, edited by Barbara and Justin Kerr, Volume IV, pp. 650-685. Kerr Associates, New York.

Tedlock, Barbara

1982 Time and the highland Maya. University of New Mexico Press, Albuquerque, New Mexico.

Tedlock, Dennis

1996 Popol Vuh: The Mayan book of the dawn of life. Revised edition. Simon \& Schuster, New York.

Thomas, Julian

2004 Archaeology and modernity. Routledge, London.

Thompson, J. Eric S.

1930 Ethnology of the Mayas of southern and central British Honduras. Field Museum of Natural History, Anthropological Series, Volume 17, Number 2. Chicago. 
1960 Maya hieroglyphic writing: An introduction. $2^{\text {nd }}$ edition. University of Oklahoma Press, Norman, Oklahoma.

Vogt, Evon Z.

1969 Zinacantan: A Maya community in the highlands of Chiapas. Belknap Press of Harvard University Press, Cambridge, Massachusetts.

1970 Human souls and animal spirits in Zinacantan. In Échanges et communications: Mélanges offerts a Claude Lévi-Strauss a l'occasion de son 60ème anniversaire, edited by Jean Pouillon and Pierre Maranda, Volume 2, pp. 1148-1167. Mouton, The Hague.

Wagner, Roy

1991 The fractal person. In Big men and great men: Personifications of power in Melanesia, edited by Marilyn Strathern and Maurice Godelier, pp. 159-173. Cambridge University Press, Cambridge, United Kingdom.

Wallace, Sandra

2011 Contradictions of archaeological theory: Engaging critical realism and archaeological theory. Routledge, London.

Watanabe, John

1990 From saints to shibboleths: Image, structure, and identity in Maya religious syncretism. American Ethnologist 17 (1): 131-150.

https://www.jstor.org/stable/645256

1992 Maya saints and souls in a changing world. University of Texas Press, Austin.

Watts, Christopher

2013 Relational archaeologies: Roots and routes: In Relational archaeologies: Humans, animals, things, edited by Christopher Watts, pp. 1-20. Routledge, London.

Weiner, Annette B.

1992 Inalienable possessions: The paradox of keeping-while-giving. University of California Press, Berkeley, California.

Welsh, W. Bruce M.

1988 An analysis of Classic lowland Maya burials. BAR International Series 409. Oxford, United Kingdom.

Whitehead, Alfred North

1978 Process and reality: An essay in cosmology [corrected edition], edited by David Ray Griffin and Donald W. Sherburne. Free Press, New York.

Zamora, Corona, Alonso

2020 Coyote drums and jaguar altars: Ontologies of the living and the artificial among the K'iche' Maya. Journal of Material Culture 25 (3): 324-347. https://doi. org/10.1177/1359183520907937 